\title{
Industrial Convergence and Media Industry Performance
}

\author{
Zhou Liang \\ School of Economics \\ Wuhan University of Technology \\ Wuhan, China \\ 1708153@qq.com
}

\author{
Yang Man \\ School of Economics \\ Wuhan University of Technology \\ Wuhan, China \\ 525875206@qq.com
}

\begin{abstract}
This paper exploits the factor analysis and inputoutput method to test the relationship between industrial convergence and media industry performance. Based on an evaluation model, the comprehensive scores of media industry in different provinces in China are empirically figured out. The results show that in the country-year-level, the convergence between the media industry and information industry has a steadily upward trend during 1995 to 2011. And in the province-year-level, the scores in the east area are relatively higher, which means the east provinces have a relatively competitive media industry. Using the input-output method, this paper measures the convergence degree between the media industry and telecommunication industry, information industry. The results show that the convergence degree of the media industry and information industry are increasing rapidly during 1995 to 2011, while that of media and telecommunication are relatively flat. Based on a production function model embed with convergence factor, we empirically find that there is an "inverted-U" shape relationship between them.
\end{abstract}

Keywords- industrial convergence; media industry; industry performance; factor analysis; input-output

\section{INTRODUCTION}

With information technology developing rapidly in the past decades, the phenomena of convergence among different industries becomes more and more common. Theoretically, the industrial convergence can destruct the boundaries between the traditional industries, and then make the convergences possible. Many literatures indicate that the industrial convergence has gradually become the new driving force of the traditional industries and economic growth (Gambardella A, Torrisi S, 1998; Stieglitz N, 2003; Gerum E, Sjurts I, Stieglitz N, 2004; Tian, 2011; Fan Hejun, 2010; McKinsey, 2011; Liya Wang, Chong Wang, 2010; Victor, Kenneth, 2013).

For the industrial convergence and industry performance, a growing literatures show that there is a significant positive relationship between them. Banker, Chang and Majumdar (1998) thinks that industrial convergence can reduce the business operation cost. Gambardella and Torrisi (1998) explore the convergence among computer, service and information industries. They find that the convergence among different industries can improve the industry performance. Also, Gerum E, Sjurts I, Stieglitz N (2004) believe that the industrial convergence can promote the evolution of the industry (Claudia Loebbecke, 2012; Xiao, 2011).

In recent years, the media industry has made a critical process. From the historical evolution perspective, the media industry has experienced three stages. The first stage is that in the 1930s the media industry mainly focuses on the broadcasting. With the television technology improved, the media industry comes into the second stage in 1950s, and in this period its contents mainly include the newspaper, broadcasting and the TV media. In the past decades, the Internet technology has changed the society critically. With the effect to the media industry increasing, currently the media industry has come into the third stage, where the new media industry grows fast. However, there are few literatures exploring the convergence of media industry. The main challenge for this work is that how to find a proper way to measure the convergence degree of media industry. Also the media industry data available is difficult to obtain.

Comparing with the existing literatures, this paper mainly contributes three strands of the literatures. First, we establish an evaluation system from the economic factors, industry scale factors and the government behavior factors. Using this model, the evaluation scores of media industry in different provinces in China are empirically figured out through the Factor Analysis Method. Second, we find a proper approach to measure the convergence degree between the media industry and telecommunication industry, and also the media industry and information industry. Third, a improved model which embeds the convergence degree factor into the traditional production function is established. And based on the model, this paper tests the relationship between the industrial convergence and the media industry performance.

The rest of the paper is organized as follows. Section 2 shows that the development status of media industry in China. Sections 3 describes the empirical analysis of the test of industrial convergence and media industry performance. And the section 4 concludes this paper.

\section{THE DEVELOPMENT STATUS OF MEDIA INDUSTRY IN CHINA}

\section{A. Analysis from National-Year-Level}

Fig. 1 shows that from 2008 to 2013, the media industry has experienced a rapid growth. In 2008, the total output of 
the media industry is about 436600 million RMB and this figure is doubled in 2013.

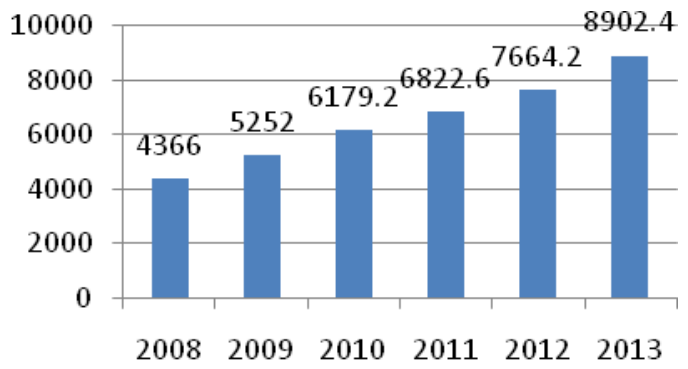

Media industry output(100 million yuan)

Figure 1. The media industry output during 2008 to 2013(Data source: "Report on development of China's media industry (2014)".)

Also in Fig.2, the media industry output growth rate is larger than the GDP growth rate during 2008 to 2013. So we can conclude that in the past few years, the role of media industry in the economic growth is become more and more critical.

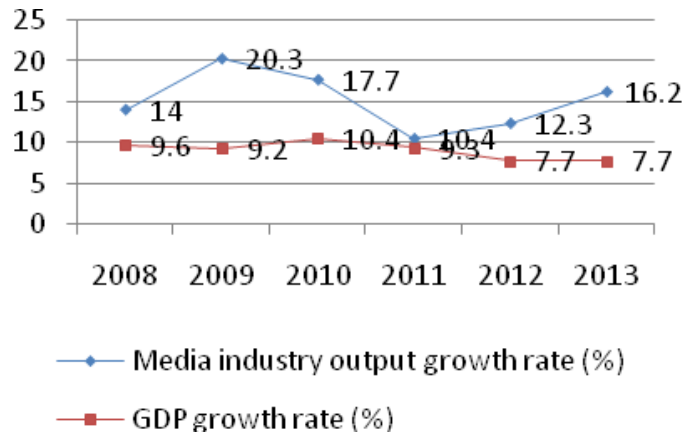

Figure 2. The media industry growth rate and GDP growth rate during 2008 to 2013(Data source: "Report on development of China's media industry (2014)", "China Statistical Yearbook (2014)")

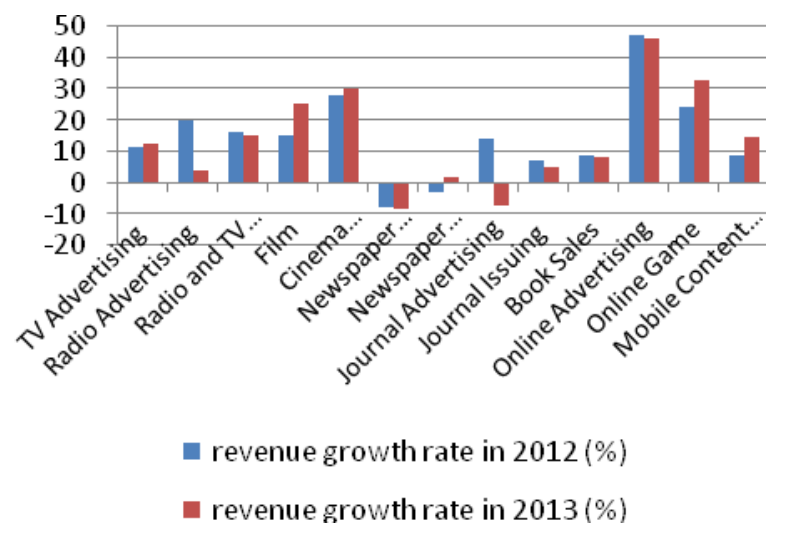

Figure 3. the revenue growth rate of media industry in China during 2012 to 2013(Data source: "Report on development of China's media industry (2014)")

The Fig.3 describes the detail revenues of subindustries in the media industry. From the bar figure we can see that the revenue shares of traditional businesses in the media industry is significantly smaller than that of the new media industries, like the online advertising, online games, and mobile content and so on. What's more, some traditional businesses' revenue growth rates are even negative, such as the newspaper advertising, newspaper publishers and the journal advertising.

\section{B. Analysis from Province-Year-Level: Based on the Factor Analysis Method}

\section{1) Establishing the Evaluation System of the Media} Industry

Using the Factor Analysis Method, we compare the differences of the development of media industry in different provinces. Before this, we establish an evaluation system of the media industry form two level indexes. The level-1 indexes include the economic factors, scale factors and government factors. In the level-2 indexes, the economic factors include the economic scale, economic structure, urbanization and income level. The scale factors include the output value, newspaper publishing, book publishing, journal publishing, broadcasting, broadcast television network trunk, public television programs, and public broadcasting programs. The government factor mainly focus on the government spending on the media industry. The detail variable descriptions are shown in table 1 .

TABLE I. THE EVALUATION SSYSTEM OF THE MEDIA INDUSTY

\begin{tabular}{|c|c|c|}
\hline $\begin{array}{l}\text { Level-1 } \\
\text { indexes }\end{array}$ & Level-2 indexes & Variable description \\
\hline \multirow{4}{*}{$\begin{array}{l}\text { Economic } \\
\text { factors }\end{array}$} & Economic scale & GDP \\
\hline & Economic structure & $\begin{array}{c}\text { The proportion of } \\
\text { tertiary industry }\end{array}$ \\
\hline & Urbanization & The urbanization rate \\
\hline & Income level & $\begin{array}{l}\text { Urban residents' } \\
\text { disposable income and } \\
\text { the net income of rural } \\
\text { residents }\end{array}$ \\
\hline \multirow{8}{*}{ Scale factors } & Output value & $\begin{array}{c}\text { sales output value of } \\
\text { publishing and printing } \\
\text { enterprises }\end{array}$ \\
\hline & $\begin{array}{l}\text { newspaper } \\
\text { publishing }\end{array}$ & $\begin{array}{c}\text { The total number of } \\
\text { newspaper publishing }\end{array}$ \\
\hline & book publishing & $\begin{array}{c}\text { The total number of } \\
\text { book publishing }\end{array}$ \\
\hline & journal publishing & $\begin{array}{l}\text { The total number of } \\
\text { journal publishing }\end{array}$ \\
\hline & broadcasting & $\begin{array}{c}\text { the covering rate of } \\
\text { broadcasting }\end{array}$ \\
\hline & $\begin{array}{c}\text { broadcast television } \\
\text { network trunk }\end{array}$ & $\begin{array}{c}\text { The total length of the } \\
\text { broadcast television } \\
\text { network trunk }\end{array}$ \\
\hline & $\begin{array}{c}\text { public television } \\
\text { programs }\end{array}$ & $\begin{array}{l}\text { Numbers of public } \\
\text { television programs }\end{array}$ \\
\hline & $\begin{array}{c}\text { public broadcasting } \\
\text { programs }\end{array}$ & $\begin{array}{c}\text { Numbers of public } \\
\text { broadcasting programs }\end{array}$ \\
\hline $\begin{array}{l}\text { Government } \\
\text { factors }\end{array}$ & $\begin{array}{l}\text { Government media } \\
\text { industry spending }\end{array}$ & $\begin{array}{l}\text { The ratio of the media } \\
\text { spending in the total } \\
\text { government spending }\end{array}$ \\
\hline
\end{tabular}

2) The Evaluation Results

Based on the evaluation model in table 1, using the Factor Analysis Method, we figure out the comprehensive evaluation on development of media industry in each province. Table 2 displays the detail results. In the table below, $\mathrm{Z}$ is the comprehensive evaluation value. And from the results of the KMO test and Bartlett sphericity test, we 
can conclude that this model is suitable for the Factor Analysis Method.

From the table, we can find that the cities like Beijing, Guangdong, Jiangsu, Zhejiang, Shandong and Shanghai have relatively higher Z-scores in the model. Consequently, we can draw the conclusion that, the development of the media industry in the east area is better than the other areas.

TABLE II. The Evaluation Results on Media Industry IN Every Province During 2010 TO 2013

\begin{tabular}{|c|c|c|c|c|c|c|c|c|}
\hline & \multicolumn{2}{|l|}{2010} & \multicolumn{2}{|l|}{2011} & \multicolumn{2}{|l|}{2012} & \multicolumn{2}{|l|}{2013} \\
\hline & Z & rank & Z & rank & Z & rank & Z & rank \\
\hline Beijing & 1.40 & 2 & 1.79 & 1 & 0.85 & 5 & 0.97 & 5 \\
\hline Tianjing & -0.36 & 24 & 0.64 & 6 & -0.34 & 22 & -0.33 & 23 \\
\hline Hebei & 0.19 & 8 & 0.00 & 11 & 0.22 & 9 & 0.34 & 8 \\
\hline Shanxi & -0.19 & 19 & -0.39 & 23 & -0.08 & 15 & -0.01 & 15 \\
\hline Inner Mongolia & -0.10 & 16 & -0.17 & 16 & -0.17 & 18 & -0.07 & 16 \\
\hline Liaoning & 0.08 & 11 & 0.18 & 9 & 0.08 & 11 & 0.12 & 10 \\
\hline Jilin & -0.27 & 20 & -0.07 & 13 & -0.17 & 19 & -0.17 & 19 \\
\hline Heilongjiang & -0.15 & 17 & -0.10 & 14 & -0.24 & 20 & -0.26 & 21 \\
\hline Shanghai & 0.14 & 9 & 1.37 & 2 & 0.42 & 6 & 0.37 & 7 \\
\hline Jiangsu & 0.95 & 3 & 0.92 & 5 & 1.30 & 2 & 1.31 & 1 \\
\hline Zhejiang & 0.87 & 4 & 1.02 & 3 & 1.28 & 3 & 1.28 & 2 \\
\hline Anhui & -0.07 & 14 & -0.22 & 18 & -0.13 & 16 & -0.11 & 18 \\
\hline Fujian & -0.06 & 13 & 0.23 & 8 & -0.01 & 13 & -0.01 & 14 \\
\hline Shanxi & -0.28 & 21 & -0.27 & 20 & -0.31 & 21 & -0.24 & 20 \\
\hline Shandong & 0.86 & 5 & 0.48 & 7 & 1.17 & 4 & 1.17 & 4 \\
\hline Henan & 0.22 & 6 & -0.15 & 15 & 0.21 & 10 & 0.22 & 9 \\
\hline Hubei & 0.10 & 10 & 0.07 & 10 & 0.24 & 8 & 0.12 & 11 \\
\hline Hunan & -0.01 & 12 & -0.27 & 19 & 0.01 & 12 & -0.10 & 17 \\
\hline Guangdong & 1.76 & 1 & 1.01 & 4 & 1.46 & 1 & 1.21 & 3 \\
\hline Guangxi & -0.35 & 22 & -0.44 & 24 & -0.38 & 24 & -0.41 & 24 \\
\hline Hainan & -0.64 & 28 & -0.30 & 21 & -0.71 & 27 & -0.74 & 27 \\
\hline Chongqing & -0.49 & 27 & -0.05 & 12 & -0.53 & 26 & -0.59 & 26 \\
\hline Sichuan & 0.20 & 7 & -0.22 & 17 & 0.41 & 7 & 0.55 & 6 \\
\hline Guizhou & -0.68 & 29 & -0.88 & 31 & -0.75 & 28 & -0.94 & 29 \\
\hline Yunnan & -0.36 & 23 & -0.49 & 25 & -0.37 & 23 & -0.45 & 25 \\
\hline Xizang & -0.73 & 30 & -0.82 & 30 & -0.85 & 29 & -1.00 & 31 \\
\hline Shanxi & -0.09 & 15 & -0.31 & 22 & -0.01 & 14 & 0.04 & 12 \\
\hline Gansu & -0.39 & 25 & -0.72 & 28 & -0.44 & 25 & -0.33 & 22 \\
\hline Qinghai & -0.90 & 31 & -0.73 & 29 & -1.11 & 31 & -1.00 & 30 \\
\hline Ningxia & -0.49 & 26 & -0.51 & 26 & -0.92 & 30 & -0.92 & 28 \\
\hline Xinjiang & -0.16 & 18 & -0.63 & 27 & -0.15 & 17 & 0.00 & 13 \\
\hline KMO-test & 0.72 & & 0.7 & & 0.75 & & 0.75 & \\
\hline Bartlett sphericity test & 0.00 & & 0.00 & & 0.00 & & 0.00 & \\
\hline
\end{tabular}

\section{EMPIRICAL ANALYSIS}

\section{A. Sample Selection}

In this section, we will set a model to figure out the convergence degree between media industry and information technology industry. Also we want to find out some differences between China and other countries. So we set our sample countries as shown in the table below.
TABLE III. SAMPLE COUNTRIES

\begin{tabular}{|l|l|l|}
\hline $\begin{array}{l}\text { Developed } \\
\text { counties }\end{array}$ & $\begin{array}{l}\text { Developing } \\
\text { countries }\end{array}$ & Data source \\
\hline AUS, USA, & CHN, RUS, & WIOT \\
CAN, FRA, & IND, BRA, & Database \\
GBR, ITA, & & \\
JPN, KOR & & \\
\hline
\end{tabular}


B. Measuring the Convergence between Media Industry and Information Technology Industry: Based on the Input-output Analysis Method

It is critical to figure out the convergence degree for the research on the relationship between media industry convergence and industry performance. A growing literature tries to find a proper approach to realize this. There are three possible methods which are Correlation Coefficient Method, Herfindahl Index, Entropy Method and Input-output Method (Fai, Tunzelmann, 2001; Gambardella, Torrisi, 1998; Xing W, Ye X, Kui L, 2011).

1) Correlation Coefficient Method

For the Correlation Coefficient Method, after figuring out both the positive and negative coefficient of technology convergence between two industries, the correlation coefficient between the two coefficients is taken as the industrial convergence degree.

\section{2) Herfindahl Index}

The equation of the Herfindahl Index Method is shown as follows.

$$
H H I=\sum\left(\frac{m_{i}}{M}\right)^{2}
$$

In the equation above, $\mathrm{m}_{\mathrm{i}}$ is the number of the patents in industry $\mathrm{i}$, and $\mathrm{M}$ is the total number of the patents. The HHI value is smaller, the convergence degree is larger.

\section{3) Entropy Method Herfindahl Index}

The equation of this method is displayed as follows.

$$
\text { entropy }=\sum p_{i} \ln \left(1 / p_{i}\right)
$$

$\mathrm{p}_{\mathrm{i}}$ is the proportion of the firm's income to the industry's income.

\section{4) Input-output Method}

The equation of the input-output method is as follows.

$$
\text { convergence }=\text { input }_{i, j} / \text { output }_{i}
$$

In the equation above, the input $t_{i, j}$ is the input of industry $\mathrm{j}$ in the production of industry $\mathrm{i}$. And output $\mathrm{t}_{\mathrm{i}}$ is the total output of industry $i$.

Among all the possible methods, we choose the inputoutput method, for its advantages on the research on the penetration and convergence between different industries. And the data required for this method is available in the WIOT database.

The input-output analysis method is used to measure the convergence degree between the media industry and other industries. In this paper, we focus on exploring the convergence among the media industry, telecommunication industry and the information industry. The detail results are shown as follows.

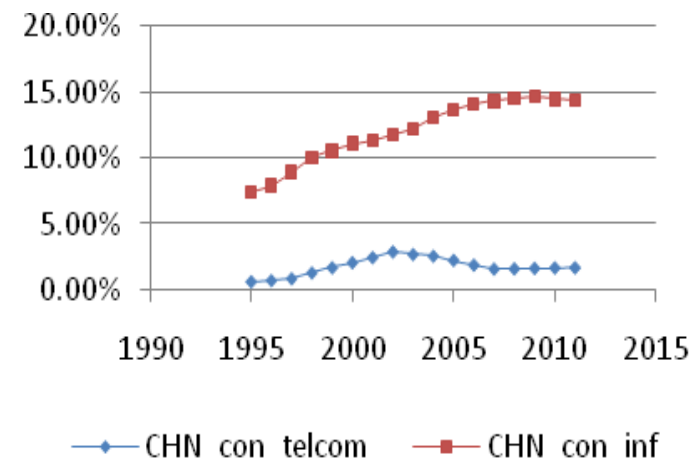

Figure 4. the convergence degrees between media industry and telecommunications industry and media industry and information industry during 1995 to 2011
Fig.4 draws the trend of the convergence degrees between media industry and telecommunications industry and media industry and information industry during 1995 to 2011. In the figure, "CHN_con_telcom" means the convergence degree between the media and telecommunication in China, and "CHN_con_telcom" means the convergence degree between the media and the information. From the figure, we can see that there are both an upward trend for the convergence degree of the media and telecommunication, also the media and information. Especially for the convergence between the media and information industry, the convergence degree is $7 \%$ in 1995, while this figure has been doubled in 2011.

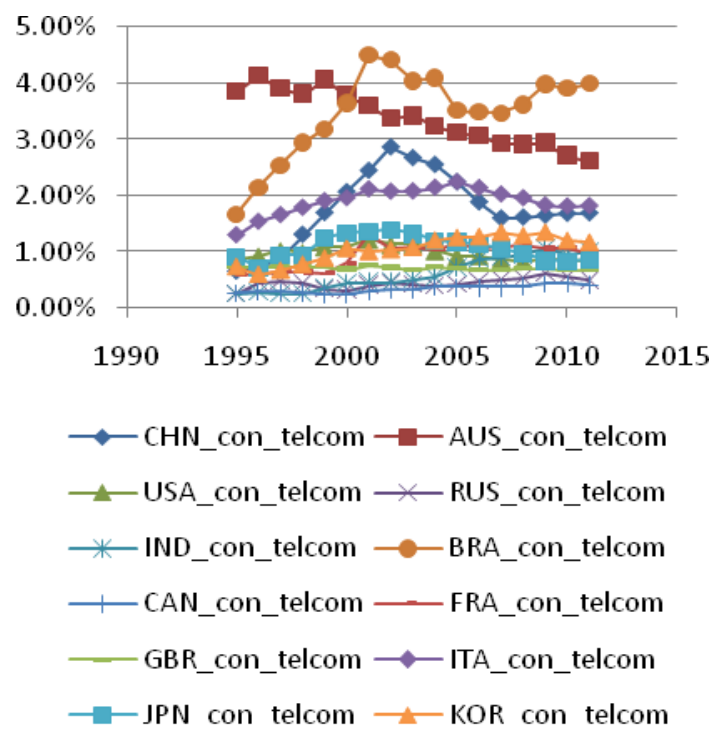

Figure 5. the convergence degree between media industry and telecommunications in different countries during 1995 to 2011

Fig. 5 shows the comparison results of the convergence between media and telecommunication. We can find that the convergence degree is relatively higher in Australia and Brazil. But the trend in most countries is flat.

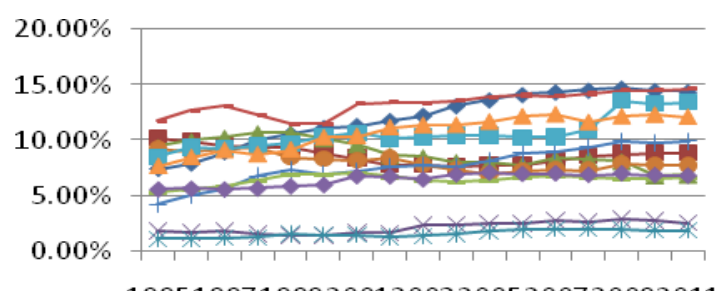

199519971999200120032005200720092011

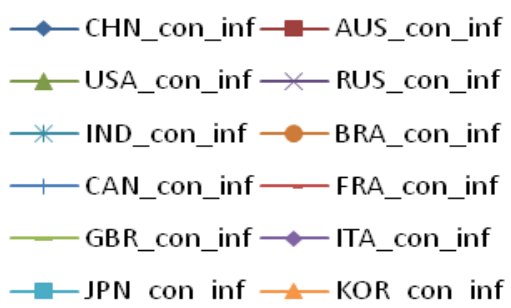

Figure 6. the convergence degree between media industry and information industry in different countries during 1995 to 2011 
Fig.6 describes the trend of the convergence degree between media industry and information industry in different countries during 1995 to 2011 . We can find that the convergence degree of China is relatively lower in 1995. While from 1995 to 2011, the convergence between the media industry and information industry has a significant upward trend. Actually, starting from 2005, the convergence degree in China is almost the top one in the selected sample countries.

\section{The Econometric Analysis of the Industrial Convergence and the Performance of the Media Industry}

\section{1) The Econometric Model}

From the analysis above, we can find that in the past decades, the convergence on media industry in China has made a great process. But the question is whether the convergence is promoting this industry performance. In order to figure out this question, we embed the convergence factor into the traditional production function.

$$
\begin{gathered}
Y_{i}=L_{i}^{\alpha *} K_{i}^{1-\alpha} * \varepsilon_{i} \\
Y_{i}=\text { Convergence }_{i}{ }^{*} L_{i}{ }^{\alpha *} K_{i}{ }^{1-\alpha *} \varepsilon_{i}
\end{gathered}
$$

In order to establish a linear model, we do the logarithmic process on the above equation. Then we can get the equation as follows.

$$
\ln Y_{i}=\text { Convergence }_{i}+\alpha_{i} \ln L_{i}+\beta_{i} \ln K_{i}+\varepsilon_{i}
$$

In the equation, $\mathrm{Y}$ is the output, convergence is the convergence degree, and $\mathrm{L}$ is labor input and $\mathrm{K}$ is the capital input.

We get our data from 2003 to 2011 from the China Statistical Yearbook. Before solving the model, we standardize the data. Then the regression results are shown in the table 4. The unit root test results show that all the variables are first-order stationary, while the convergence between media and telecommunication is second-order stationary. So we get L.tel in our model.

\section{2) The Results}

In table 4, we can see that in the model (1), the coefficient of inf is significant positive and the coefficient if inf2 is significant negative. Also, we can get the same information for L.tel and L.tel2. The results mean that there is an "inverted- U" relationship between the convergence and media industry. Consequently, as the degree of the convergence increasing, the effect on the media industry performance could be positive at the beginning, and then be negative.

TABLE IV. THE REGRESSION RESULTS

\begin{tabular}{|l|l|l|}
\hline Variables & $(1)$ & $(2)$ \\
\hline inf & $583.9044^{*}$ & \\
\hline inf2 & $-2373.293^{*}$ & \\
\hline L.tel & & $6.851406^{*}$ \\
\hline L.tel2 & & $-25.69185^{*}$ \\
\hline L & $15.03767^{* *}$ & 2.952152 \\
\hline K & 1.421971 & -0.0893338 \\
\hline gov & -1.94912 & 0.434775 \\
\hline constant & -37.54815 & -0.7195701 \\
\hline R-squared & 0.9836 & 0.9983 \\
\hline
\end{tabular}

Notes: * means the coefficients pass the significant test under the 10\% confidential level. inf2 is the square of inf and tel 2 is the square of tel.

\section{CONCLUSIONS}

Our paper establishes an evaluation system and empirically figures out the evaluation scores of media industry in different provinces in China, using the Factor Analysis Method. Also, we use the input-output method to measure the convergence degree between the media industry and telecommunication industry, and also the media industry and information industry. From 1995 to 2011, the convergence between the media industry and information industry has a significant upward trend. Based on the econometric model, we test the relationship between the convergence and the industry performance, and results show that the relationship is an "inverted-U" shape.

\section{ACKNOWLEDGMENT}

This paper is funded by National Social Science Fund (13BJY02) and Generalized Virtual Economy Research projects (GX2014-1014(Y)). We also thank the suggestions of Prof. Wang Renxiang of Wuhan University of Technology.

\section{REFERENCES}

[1] Gambardella A, Torrisi S, "Does technological convergence imply convergence in markets? Evidence from the electronics industry". Research policy, 1998,27( 5) ,pp.445-463.

[2] Stieglitz N, "Digital dynamics and types of industry Convergence: The evolution of the handheld computers market". The Industrial Dynamics of the New Digital Economy, 2003, pp. 179-208.

[3] Tian Jianlan, The Influence of Industry Convergence on Sustainable Development of Cultural Industry, 8th OAPS Working Paper Series, 2011.

[4] Fan Hejun, "Industrial organization theory", Beijing: Economic Management Press, 2010.

[5] McKinsey Global Institute "Big Data: The next frontier for innovation, competition and productivity", 2011, 19. Avaliable at: http://www.mckinsey.com/insights/business_technology/big_data_ the_next_frontier_for_innovation

[6] Liya Wang, Chong Wang, "Contemporary Digital Media Revolution and New Trends in Media Regulation", Scientific Research, 2010, pp. 326-330.

[7] Victor, Kenneth, "Big Data era", Zhejiang People's Publishing House, 2013.

[8] Gerum E, Sjurts I, Stieglitz N, "Industry Convergence and the Transformation of the Mobile Communications System of Innovation", ITS 15th Biennial Conference, Berlin, Germany, 2004.

[9] Banker, Chang, Majumdar, "Economies of scope in the US telecommunications industry". Information Economics and Policy, 1998, 10( 2), pp. 253-272.

[10] Claudia Loebbecke, "The Emergence of Ebooks: Just Another Media Industry Joining the Converging Digital World? An Explorative Study on User Preferences and Industry Structure Changes", 2012, Available at SSRN: http://ssrn.com/abstract=1986386.

[11] Xiao Zanjun, "Western media industry convergence, competition and regulation", Beijing: China Books Publishing House, 2011.

[12] Fai, Tunzelmann, "Industry-Specific competenciesand converging technological systems: evidence from patents", Structural Change and Economic Dynamics, 2001, 12( 2), pp. 141-171.

[13] Xing W, Ye X, Kui L, "Measuring convergence of China's ICT industry: An input-output analysis", Telecommunications Policy, 2011, 35( 4), pp. 301-313. 